\title{
Nangkring khas millennial: Studi komparatif gaya hidup dan interaksi pemuda di Cafe Sudimoro dan Rowoklampok
}

\author{
Alifia Putri Azahra, Nanda Harda Pratama Meiji* \\ Universitas Negeri Malang, Jl. Semarang No. 5 Malang, Jawa Timur, Indonesia \\ *Penulis korespondensi, Surel: nanda.harda.fis@um.ac.id
}

Paper received: 01-04-2021; revised: 15-04-2021; accepted: 30-04-2021

\begin{abstract}
Abstrak
Berbagai kajian mengenai pedesaan masih terfokuskan pada berbagai proses pembangunan infrastruktur dan ekonomi yang tertinggal dibandingkan perkotaan. Sampai saat ini masih jarang yang membahas mengenai gaya hidup dan proses interaksi antar pemuda di wilayah pedesaan. Gaya hidup dan interaksi sering sekali menjadi tolak ukur tingkat kesejahteraan ekonomi yang dimiliki para pemuda. Oleh karena itu, gaya hidup dan proses interaksi sosial akan menjadi hal yang sangat menarik untuk diteliti yang dilakukan di wilayah pedesaan yakni Rowoklampok, Senggreng. Disisi lain gaya hidup dan interaksi merupakan cara seorang pemuda untuk melakukan berbagai aktivitas nongkrong di cafe. Penelitian ini bertujuan untuk membedakan antara gaya hidup dan interaksi pemuda di cafe Sudimoro dan Rowoklampok dalam memanfaatkan waktu luang yang mereka miliki. Jenis penelitian ini adalah studi pustaka dimana data diperoleh dari artikel, jurnal, skripsi, tesis dan sejenisnya. Dari hasil penelitian ini mengantarkan pada kesimpulan mengenai gaya hidup nangkring dan proses interaksi sosial pemuda sudah ada sejak mereka kecil. Namun, jika dahulu banyak sekali pemuda yang nangkring di pinggiran desa sekarang menjadi lebih suka nongkrong di cafe dan akhirnya memunculkan inovasi pendirian cafe agar menarik para pemuda nangkring disana. Selain itu, cafe di pedesaan lebih identik dengan wisata keluarga, sedangkan di perkotaan lebih identik dengan nangkring bersama teman untuk berkumpul dan membahas banyak hal.
\end{abstract}

Kata kunci: gaya hidup; interaksi sosial; nangkring; pemuda pedesaan dan perkotaan

\section{Pendahuluan}

Urgensi penelitian ini berasal dari kebiasaan masyarakat perkotaan dan pedesaan khususnya para pemuda dalam mengkonsumsi kopi setiap harinya bahkan sudah menjadi kebiasaan yang mendarah daging untuk menyeduh kopi sebagai rutinitas mereka setiap harinya. Namun, banyak sekali proses gaya hidup dan terjalinnya interaksi yang berbeda antara para pemuda yang hidup di wilayah perkotaan dengan wilayah pedesaan. Disisi lain, setiap wilayah juga memiliki kebiasaan dalam minum kopi bersama keluarga, sahabat maupun kekasih mereka di setiap waktu luang yang mereka miliki, bahkan mereka akan mencari waktu luang untuk sekedar minum kopi dan berjumpa bersama menghabiskan waktu yang mereka miliki. Kopi juga dapat dikonsumsi oleh semua orang di berbagai penjuru dunia dengan memberikan manfaat kepada setiap individu seperti mengkonsumsi kopi menjadi lebih terjaga dari tidurnya, dapat mengurangi stress, dan memberikan energi yang lebih baik dari sebelumnya (Bhara M, 2009).

Di era millenials, para pemuda lebih identik dengan budaya nangkring untuk menghabiskan waktu luang yang mereka miliki hanya untuk ngopi maupun berjumpa dengan teman untuk membahas berbagai hal. Namun, bagi para pemuda nangkring sudah menjadi bagian gaya hidup dan munculnya interaksi baru antara individu dengan individu lainnya, dimana keduanya sama-sama memiliki kepentingan dengan berbagai aktivitas utama mereka 
seperti kesibukan yang mereka miliki baik mereka yang mengenyam pendidikan di berbagai tingkatan mulai SD - Perguruan Tinggi maupun mereka yang sedang menjalankan pekerjaanya.

Gaya hidup yang dilakukan pemuda lebih kepada proses penghabisan waktu luang yang mereka miliki untuk melakukan berbagai macam aktivitas yang kurang bermanfaat di setiap harinya, aktivitas tersebut sengaja mereka lakukan atas dasar hobi, kesedihan, dan kesenangan sesaat yang muncul dalam diri mereka untuk memperbaiki perasaan mereka di saat itu dengan menunjang status sosial yang mereka miliki (Kaparang 0. M, 2013).

Saat ini, banyak sekali pemuda yang nongkrong di cafe untuk minum kopi dan menghabiskan waktu luang mereka untuk melakukan aktivitas yang tidak begitu penting kini sudah menjadi budaya yang akan terus menerus terjadi, sebab sekarang cafe yang kini dijadikan sebagai tempat nongkrong sudah mengalami banyak sekali perkembangan secara material maupun non material. Dimana dulunya mereka hanya bisa menikmati kopi dengan nangkring di pinggir jalan sembari untuk mengobrol dan menghabiskan waktu luang tetapi sekarang ini mereka dapat menikmati kebersamaan di tempat yang lebih baik dan nyaman seperti hotel berbintang yang menggunakan berbagai nama dan istilah untuk menarik para pecinta kopi (Herlyana E, 2014).

Berbagai macam bentuk gaya hidup dan proses terjalinnya interaksi baru antara individu satu dengan individu lainnya yang dijelaskan di atas, sangat berbeda dengan kenyataan yang tengah ada di wilayah pedesaan. Budaya nongkrong yang ada di wilayah pedesaan lebih bersifat kelompok dan tidak mementingkan seberapa tinggi tingkat sosial yang mereka miliki, tetapi mereka pemuda desa melakukan nangkring untuk mementingkan rasa kebersamaan yang didukung oleh suasana yang begitu indah di atas rawa. Selain itu, cafe yang ada di wilayah pedesaan lebih menyuguhkan berbagai objek atau spot untuk bermain bersama sambil menikmati kopi diatas apungan rawa. Hal ini terjadi di Senggreng, dimana wilayah tersebut merupakan wilayah pinggir dari Kota Malang, di sana juga mempunyai budaya nangkring seperti orang kota,

Gaya hidup yang ada di wilayah pedesaan tidak jauh berbeda dengan gaya hidup masyarakat yang ada di perkotaan, seperti di desa senggreng ini yang memiliki gaya hidup seperti pemuda di perkotaan Malang. Namun, meskipun begitu banyak sekali kekurangan dalam pembangunan cafe yang ada di pedesaan yang ingin berusaha menyamakan dengan cafe modern yang ada di perkotaan, namun terdapat hal yang sama seperti di perkotaan yaitu dengan banyaknya para pemuda yang berbondong-bondong datang ke lokasi tersebut untuk menghabiskan waktu luang mereka dalam mengobrol dan bersantai bersama rekan dan keluarga mereka.

Oleh karena itu, kehadiran peneliti disini untuk menganalisis perbedaan gaya hidup dan interaksi sosial yang terjalin antara individu dengan individu lainnya di pedesaan maupun perkotaan yaitu tentang nangkring khas milenial terkait gaya hidup dan interaksi sosial yang terjadi di cafe Sudimoro dan Rowo Klampok. Penelitian ini menggunakan metode studi pustaka, dimana hasil data dilihat dari artikel, jurnal, skripsi, tesis, dan sebagainya yang sesuai dengan tujuan awal dalam penelitian ini tentang perbedaan interaksi sosial dan gaya hidup para pemuda milenial itu terjadi dalam nyangkruk dan minum kopi di kafe yang ada di pedesaan dan wilayah perkotaan. 
Studi tentang gaya hidup dan motivasi para pemuda dalam ngopi di berbagai wilayah perkotaan sudah banyak dilakukan. Sebuah artikel dari (Dwi Fajar Khamdani, 2014), melakukan penelitian berdasarkan tentang sudut pandang yang telah mendialogkan komunitas para pecinta ngopi di wilayah Sarijan Malang. Selain itu, faktor yang mempengaruhi gaya hidup mereka untuk nongkrong di kopian Sarijan Malang diantaranya adanya agama dan kepercayaan yang dimiliki oleh setiap individu tersebut, banyak individu yang nangkring karena menurut kepercayaan yang mereka miliki nangkring di kopian bersama teman dekat dapat memulihkan rasa lelah dan kantuk. Selain itu, agama dan kepercayaan juga dijadikan sebagai topik yang dapat dibicarakan dalam nangkring di kopian. Adanya teknologi informasi yang ada juga dapat membuat pemuda yang nangkring di kopian dapat menemukan ide atau gagasan baru untuk dikembangkan atau hanya mendiskusikan gagasan tersebut dengan teman ngopi. Faktor lain, yaitu adanya pengaruh gaya hidup atau hobi yang dimiliki oleh setiap individu, dimana dalam ngopi mereka bisa menyamakan status sosial yang ada dalam realitas kehidupan mereka. (Nur Abriani Hidayatullah, 2013) yang melakukan riset tentang kebudayaan nongkrong di kafe yang instagramable untuk menunjang gaya hidup mahasiswa dalam realitas sosial maupun non realitas sosial. Dari kajian tersebut, dapat dilihat hasil dari penelitian yang dibuat, diantaranya terdapat bukti setiap mahasiswa yang melakukan nangkring di kopian, mereka hanya sekedar ingin mencari tempat untuk berfoto ria dan di upload dalam sosial media mereka untuk menunjukkan eksistensinya di dunia Maya. Selain itu, mahasiswa yang nangkring di kopian tersebut hanya ingin melihat menu makanan yang disajikan untuk difoto dan upload dalam jejaring sosial yang mereka miliki. Setiap mahasiswa memilih cafe sebagai tempat yang dijadikan tangkringan yang aman dan nyaman untuk berdiskusi dan mengobrol bersama teman. Hal ini yang membuat mahasiswa mengunjungi berbagai macam kafe, ketika kafe tersebut telah menawarkan kriteria yang diinginkan oleh mahasiswa maka akan menjadikan intensitas untuk sering mengunjungi kafe tersebut. Inilah yang menjadikan perilaku yang dilakukan mahasiswa tersebut sebagai bentuk dari gaya hidup mereka selama berada di kota besar. (Ahmad Jaenudin, 2015) peneliti berfokus tentang alasan mahasiswa dalam menjalani rutinitas nongkrong di kafe bersama teman-temannya. Dilihat dari setiap mahasiswa melakukan nongkrong bersama teman di sebuah kafe atas dasar kejenuhan yang mereka rasakan saat itu dan gaya hidup mahasiswa di perkotaan yang cukup mewah untuk memenuhi keinginan mereka yang sesaat, demi untuk menunjang kebutuhan mereka dan kebiasaan mereka. Kafe dapat membebani keuangan mereka di setiap harinya dengan gaya hidup yang relatif hedonisme. Selain itu, nongkrong memiliki motivasi tertentu bagi mahasiswa diantaranya membuat mahasiswa tersebut memperoleh informasi baru tentang suatu hal yang mereka tidak ketahui sebelumnya, dan motivasi lainnya karena ajakan teman untuk melakukan relaxasi dengan ngopi dan nongkrong di cafe. (Dea Ayu Pramitha \& V. Indah Sri Pinasti, M,Si, 2007) sedangkan kopian yang ada di wilayah Jogja juga menjadi destinasi ngopi atau nyangkruk bersama teman mereka. Nongkrong di warung kopi sebagai bagian dari gaya hidup mahasiswa di kota Jogja tersebut. Dalam nongkrong mahasiswa juga memiliki berbagai macam kegiatan seperti menikmati suasana yang ada di kafe tersebut, mengerjakan tugas, berdiskusi, dan bermain musik bersama teman-teman. Kebiasaan nongkrong di malam hari ini menjadikan mahasiswa mengantuk di keesokan harinya. Selain itu, memiliki faktor lain yang mempengaruhi gaya hidup pemuda saat menyantap kopi diantaranya yaitu budaya yang terjadi di lingkungan sekitar yang suka nongkrong dan sebagai ajang pamer kelas sosial yang dimiliki oleh setiap mahasiswa. Selain itu ada juga yang memiliki kelas sosial biasa tetapi ingin menyetarakan kelas sosial tersebut dengan kondisi lingkungan yang baru. (Ahmad Fauzi dkk.,2017) maraknya pembangunan kafe di wilayah Denpasar Bali 
menarik minat mahasiswa. Anak muda yang datang ke kafe tersebut kebanyakan tidak melihat seberapa mahal harga makanan yang ditawarkan di café tersebut entah mahal atau tidaknya, setiap pemuda yang berdatangan kesana tidak memikirkan uang yang akan mereka keluarkan dalam sekali nongkrong di kafe tersebut. Selain itu, banyak pemuda yang mengesampingkan biaya transportasi untuk pergi nongkrong dari pada biaya untuk pergi ke kafe di pinggir jalan. Dari hal tersebut, dapat dilihat bahwa setiap bentuk eksistensi yang dilakukan oleh anak muda merupakan bagian dari budaya untuk mementingkan gaya hidup mereka dalam kehidupan nyata.

Penelitian ini muncul dari maraknya kajian tentang gaya hidup para pemuda di era milenial dalam menghabiskan waktu luang mereka dengan nangkring di cafe maupun warung kopi. Namun, sangat disayangkan banyak sekali hasil tulisan mereka yang lebih condong meneliti tentang gaya hidup dan interaksi yang terjadi di cafe-cafe kota besar, dan tidak condong melihat bagaimana bentuk interaksi sosial yang terjalin di wilayah pedesaan dan bagaimana gaya hidup pemuda milenial yang ada di desa dalam mengembangkan budaya nangkring di kopian atau cafe. Sebagian besar kajian yang ada lebih cenderung menggunakan lokasi mereka yang ada di wilayah perkotaan saja, seperti halnya kajian yang dituliskan diatas.

Oleh karenanya, artikel ini akan menambahkan berbagai kajian mengenai perbedaan gaya hidup dan interaksi para pemuda di cafe Sudimoro dan Rowo Klampok Sedangkan, dengan pemilihan lokasi penelitian yang berada di wilayah pedesaan di Senggreng kabupaten Malang. Dalam lokasi yang dipilih oleh peneliti ini dapat memunculkan hasil penelitian yang berbeda serta dapat memunculkan berbagai tipologi atau pemikiran masyarakat terkait pembangunan infrastruktur cafe yang ada di wilayah pedesaan.

Lokasi yang jauh dari perkotaan, serta akses jalan yang tidak semulus dan sebagus di wilayah kota. Serta berbagai penelitian terkait dengan interaksi sosial yang mempengaruhi gaya hidup pemuda yang tengah dilakukan berjam-jam dalam nangkring dengan menikmati kopi bersama teman dan keluarga di lingkungan Rowo Klampok dan Sudimoro.

\section{Metode}

Penelitian ini menggunakan metode studi pustaka yaitu sebuah penelitian yang mengacu kepada informasi yang relevan terkait topic dan permasalahan yang menjadi objek penelitian tersebut, dimana penelitian tersebut sumber informasinya dapat diperoleh dari data penelitian sebelumnya, buku, artikel, skripsi, internet, tesis, disertasi, ensiklopedia (Sugiyono, 2015).

Penelitian ini mengenai perbedaan gaya hidup dan proses interaksi yang dilakukan para pemuda di café Sudimoro dan Rowoklampok dalam nyangkruk dan minum kopi. Penelitian ini dilakukan di desa Senggreng tepatnya di Cafe Apung Rowoklampok Kecamatan Sumberpucung, Kabupaten Malang serta juga melakukan penelitian di wilayah cafe Sudimoro, Jalan Soekarno Hatta Malang.

Pemilihan lokasi ini didasarkan atas keunikan yang dimiliki oleh para pemuda yang ada di Rowo Klampok tersebut, sebab ini merupakan cafe pertama yang dibangun diatas rawa yang tengah viral di lingkungan masyarakat Kota Malang, karena arsitektur yang dibuat bernuansa alam, dibandingkan dengan cafe yang ada di pinggiran kota. Selain itu, untuk membedakan antara gaya hidup dan proses interaksi yang terjalin diantara pemuda di wilayah cafe Sudimoro maupun Rowoklampok. 
Teknik pengumpulan data ini dapat dilihat dari hasil penelitian-penelitian terdahulu yang sama-sama membahas mengenai gaya hidup para pemuda ngopi, selain itu, teknik studi kasus merupakan teknik awal dalam proses pengumpulan data agar penelitian tersebut mendapatkan hasil penelitian yang lebih kredibel dan sesuai dengan judul dan topic permasalahan peneliti. Sumber data yang diperoleh bisa melalui berbagai dokumen penting seperti gambar, foto, artikel, jurnal, skripsi, tesis, disertasi, dan buku (Sugiyono, 2015).

Pemilihan data ini didasarkan atas rumusan masalah yang dibuat oleh peneliti yang dapat disesuaikan dengan situasi dan kondisi pada lingkungan penelitian yang nantinya dikembangkan dengan melihat hasil dokumentasi yang diperoleh peneliti di lapangan. Selain itu, dalam melakukan ini, peneliti memfokuskan dengan teori yang dikemukakan oleh (George Torkildsen, 1983) dalam bukunya yang berjudul "Leisure and recreation management".

Dalam teori menjelaskan mengenai pemanfaatan waktu luang yang disesuaikan dengan situasi dan kondisi. Disini peneliti menggunakan konsep teori leisure as activity dan teori leisure class social. Sebab dalam penelitian mengaitkan antara kawasan urban yang mengalami perubahan serta pertumbuhan yang sangat cepat. Disisi lain, memiliki perbedaan antara kelas sosial yang dimiliki oleh para pemuda dalam melakukan budaya nyangkring di café Sudirmoro dan Rowoklampok. Namun, dengan adanya waktu luang yang dimiliki kelas sosial paling tinggi menjadikan waktu luang mereka sebagai sebuah aktivitas atau kesenangan sesaat yang dilakukan para pemuda dalam memenuhi kebutuhan dalam menghabiskan waktu luang yang mereka miliki.

\section{Hasil dan Pembahasan}

\subsection{Perbandingan Gaya Hidup Dan Interaksi Sosial Pemuda Di Wilayah Cafe Sudimoro Dan Rowoklampok}

Saat ini para pemuda millennial pasti lebih mengenal istilah role model, dimana role model ini mengacu pada prinsip gaya hidup yang juga menjadi sebuah perilaku yang sering dilakukan oleh para pemuda yang memiliki kelas sosial atas untuk menunjukkan eksistensinya. Sehingga, perilaku dan kehadiran pemuda dapat diterima oleh masyarakat. Seiring perkembangan zaman, terutama zaman milenial ini, para pemuda menginginkan diri mereka seperti orang lain, mereka lebih berimitasi untuk menjadi sama persis seperti orang lain dan tidak menjadi dirinya sendiri.

Sedangkan, interaksi sosial akan terus terjadi dalam kehidupan para pemuda jika mereka memulai suatu hubungan, misalnya saja seperti pada budaya nyangkrung para pemuda yang berdatangan untuk sekedar nyangkrung sembari minum kopi pastinya memiliki interaksi sosial yang terjalin antara si pemuda dengan teman bahkan para barista. Namun, disisi lain prose interaksi itu akan memiliki kelumpuhan jika seorang pemuda memiliki sifat individual dan memilih milih teman, dimana teman yang memiliki status sosial yang tinggi maka mereka akan terus melakukan interaksi dengan teman mereka, begitupun sebaliknya.

Berbagai tindakan ini menurut (Sears dkk., 1985) menilai bahwa setiap tindakan terkait interaksi dan gaya hidup tersebut akan dilakukan oleh setiap orang sebab termasuk kedalam konformitas seseorang dalam melakukan tindakan tersebut karena faktor dari individu lain yang sudah melakukan tindakan tersebut sebelumnya. Pemuda melakukan tindakan konformitas ini dikarenakan mereka ingin melakukan berbagai perubahan pada diri mereka 
baik status sosial maupun penampilan mereka agar para pemuda tersebut dapat diterima dalam kelompok sosial yang baru (Mappiare, 1982).

Sedangkan, jika dikaji dalam konsep sosiologi pemuda merupakan seorang yang melakukan berbagai bentuk gaya hidup karena pengaruh lingkungan disekitar mereka. Namun, terdapat perbedaan yang cukup signifikan mengenai para pemuda yang memiliki perbedaan generasi, dimana pemuda yang kelahiran tahun generasi old pastinya mereka mungkin melakukan nyangkruk sebagai sebuah refreshing diri dari kejenuhan, sedangkan para pemuda memiliki banyak alasan untuk melakukan nangkring di café. Bahkan para pemuda rela mengeluarkan banyak uang untuk mendapatkan fasilitas café yang memadai dibandingkan dengan generasi old yang tidak memikirkan tempat asalkan tempat tersebut nyaman, murah, dan bisa untuk berkumpul dengan keluarga (Mannheim K, t.t.).

Gaya hidup dan proses interaksi memang menjadi salah satu bagian terpenting yang sering dilakukan anak muda, dan hal ini selalu berkaitan dengan budaya populer di lingkungan masyarakat. Hal ini dapat dilihat dari kesamaan yang dimiliki oleh para pemuda untuk terus menjaga eksistensinya dalam gaya hidup dimana gaya hidup yang mereka inginkan dapat dilihat dari internet, sebab internet menyajikan semua terkait gaya hidup yang menjadi populer di lingkungan pemuda (Hull dkk., t.t.). Budaya populer sendiri ini dapat diakses oleh semua kalangan pemuda yang tidak memandang daerah, ras, suku, agama, usia, dan gender yang dimiliki, tetapi budaya populer dapat diakses secara bebas oleh siapapun (Storey, t.t.).

Oleh karena itu, para pemuda yang berada di wilayah pedesaan juga masih dapat mengakses gaya hidup yang dapat disesuaikan dengan kemampuan mereka. Sedangkan di wilayah perkotaan para pemuda akan melakukan berbagai cara agar gaya hidup yang mereka inginkan dapat terpenuhi dan tetap eksis dalam nyangkruk di café-café mahal.

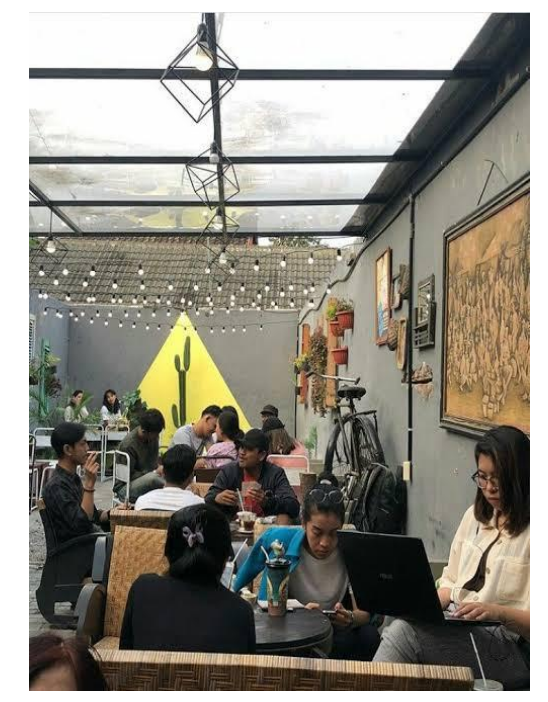

\section{Gambar 1. Suasana Café di Perkotaan Sumber: https://google.id/}

Dari gambar diatas dapat dilihat bahwa café yang ada di perkotaan lebih cenderung digunakan oleh para pemuda baik mahasiswa maupun tingkat pendidikan lain untuk mengerjakan tugas dan mengobrol dengan teman. Dan banyak diantara pemuda yang hidup di perkotaan masih mementingkan gaya hidup yang lebih bagus dan terus menyamarkan gaya 
hidup mereka agar dapat terlihat mewah dan berkelas. Selain itu, pemuda yang melakukan nyangkruk di café Sudimoro ini lebih sedikit aktif dalam melakukan interaksi sosial, sebab banyak sekali pemuda yang lebih asyik bermain game online bersama teman-teman mereka dan tidak melakukan kontak sosial langsung dengan baik.

Selain itu, café-café yang ada di perkotaan lebih cenderung memiliki arsitektur yang instagramable yang dapat mendorong minat para pencipta kopi untuk datang kesana sembari menikmati keindahan lokasi café dan menu yang disajikan. Para pemuda yang melakukan nyangkrung di café perkotaan antara pemuda perempuan dan laki-laki begitu berimbang dan tidak ada batasan jam. Selain itu wilayah café di perkotaan lebih memberikan fasilitas 24 jam untuk para pemuda melakukan nyangkrung sembari ngopi.

Disisi lain, para pemuda yang melakukan nangkring di café lebih identic untuk memanfaatkan waktu luang mereka demi bertemu bersama teman dan mencari wifi gratis dan lebih main game. Selain itu, café di perkotaan juga lebih memberikan fasilitas live music, dimana terdapat music-music yang dihadirkan oleh pemilik kafe sebagai hiburan bagi para pendatang. Dan membuat interaksi antara individu dapat terjalin dengan baik meskipun tidak seperti di café yang ada di wilayah pedesaan. Hal ini dilakukan untuk meminimalisir individual yang dimiliki para pemuda yang condong berteman dan berinteraksi sesuai gaya hidup yang sama dan segerombolan teman dekatnya saja.

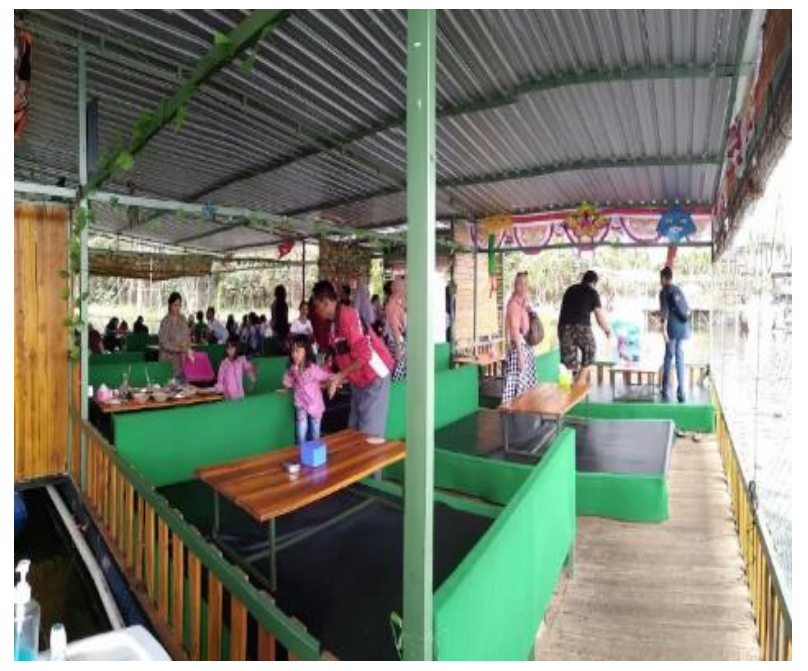

\section{Gambar 2. Suasana Café di Pedesaan Sumber: https://fauzihakim.com}

Gambar diatas merupakan café yang ada di pedesaan yaitu café Rowoklampok, disebut rowo karena lokasinya berada di atas rawa. Café ini didesain dengan gaya apung dan memiliki berbagai fasilitas wahana permainan dan makanan, serta aneka minuman yang hal ini sangat membedakan dengan café di perkotaan, dimana wilayah perkotaan hanya menyediakan live music dan wifi serta spot café yang menarik untuk menarik minat para pengunjung.

Tetapi di wilayah pedesaan ini café dijadikan sebagai sebuah objek wisata dan tempat nongkrong bersama keluarga, baik juga dilakukan sebagai tempat yang disewa untuk melakukan proses prewedding, dan arisan keluarga maupun arisan sosialita. Meskipun café ini berada di wilayah pedesaan tetapi tidak para pemuda yang ada di wilayah pedesaan masih 
begitu menjaga gaya hidup mereka agar gaya hidup para pemuda desa tidak kalah dengan para pemuda yang hidup di perkotaan.

Tetapi disisi lain para pemuda yang memiliki perekonomian menengah kebawah mereka tidak menginginkan gaya hidup yang berlebihan layaknya seorang pemuda di perkotaan, mereka lebih bersyukur sudah nangkring di café yang sudah terkenal tersebut. Sedangkan, para pemuda kota lebih memanfaatkan waktu luang mereka selain untuk nangkring mereka juga menghabiskan uang untuk pergi ke mall, membeli makanan cepat saji, fashion dan nonton bioskop. Sedangkan, para pemuda desa selalu bersyukur ketika memiliki waktu luang menghabiskan bersama keluarga untuk nangkring di café dan berfoto selfie ria.

\subsection{Transformasi Café Sudimoro dan Rowoklampok Sebagai Tempat Pemuda Nongkrong}

Banyak sekali para pemilik modal yang menginginkan agar usaha yang didirikan dapat menuai banyak sekali keuntungan yang luar biasa, oleh karena itu merelakan untuk memperbaiki arsitektur dan menu makanan yang disajikan sehingga para pemuda yang datang tidak bosan dengan menu yang disajikan tersebut. Pemuda yang hidup di wilayah perkotaan sering sekali menghabiskan waktunya untuk pergi nonton bioskop, makan di KFC, Mc Donalds, dan nangkring di warung kopi. Tetapi, siapa sangka jika seiring perkembangan zaman warung kopi pinggiran kini sudah menjadi café yang menyediakan berbagai fasilitas untuk menarik minat pemuda untuk menjadikan café tersebut sebagai tempat angkringan. Hal ini juga dilakukan di pedesaan dimana dulunya Rowoklampok ini dikenal sebagai danau yang hanya untuk pemuda memancing dan nangkring sembari menghabiskan waktu luang yang mereka miliki, tetapi saat ini mereka bisa menghabiskan waktu di café bersama keluarga.

Sebelum tahun 2018 di wilayah Rowoklampok tersebut hanya sebatas rawa untuk dimanfaatkan para pemuda untuk lokasi pemancingan dan nangkring bersama teman dan keluarga, karena lokasinya yang sejuk yang bikin pemuda disana menjadi betah untuk berlama-lama. Tetapi disana juga memiliki warung kopi yang dijadikan sebagai tempat nangkringan bukan seperti saat ini, sebab dulu café atau warung kopi tersebut masih memiliki interior yang berbeda daripada kafe yang terkenal saat ini. Dimana kafe pada masa itu di wilayah pedesaan masih memiliki interior yang sangatlah sederhana yang memiliki keterbatasan dalam arsitektur maupun perlengkapannya seperti kursi dan meja yang tak seperti saat ini meja dan kursi sudah dihias sedemikian rupa untuk menarik perhatian para pemuda untuk nangkring.

Seiring berjalannya waktu akhirnya café yang ada di pedesaan ini memiliki inovasi terkait interior atau hiasan dinding seperti memberikan lampu tumbler, quotes, selendang yang dihias di pinggir dan lampu neon tradisional agar bernuansa klasik. Selain itu, meyeduhkan menu seperti layaknya café di perkotaan seperti friendfries, roti bakar, burger, pizza, mie pedas, roti john, dan beraneka menu minuman dan kopi yang disajikan. Hal ini dilakukan oleh pemilik usaha agar dapat menarik minat pemuda agar berkunjung sambil nagkring dan menikmati kopi.

Selain itu café yang dibangun di Rowoklampok ini memberikan berbagai wahana seperti flying fox, kapal apung, perahu, pemancingan hal ini dilakukan agar para pemuda yang nangkring tidak bosan dengan nangkring seperti itu karena sudah terlalu monoton, sedangkan dengan adanya wahana di sini memperbaiki mood para pemuda yang datang dan bermain 
sambil menikmati senja di sore hari bersama kopi dan hidangan lainnya. Tetapi, disini juga menyediakan live music tradisional yang diiringi oleh alat tradisional berpadu dengan alat modern seperti gamelan, piano, dan gitar. Suasana music ini membuat pemuda menjadi betah untuk berlama-lama nangkring di café tersebut. Disisi lain, menu makan yang disajikan pun dengan harga yang begitu murah dan terjangkau di kantong para pemuda.

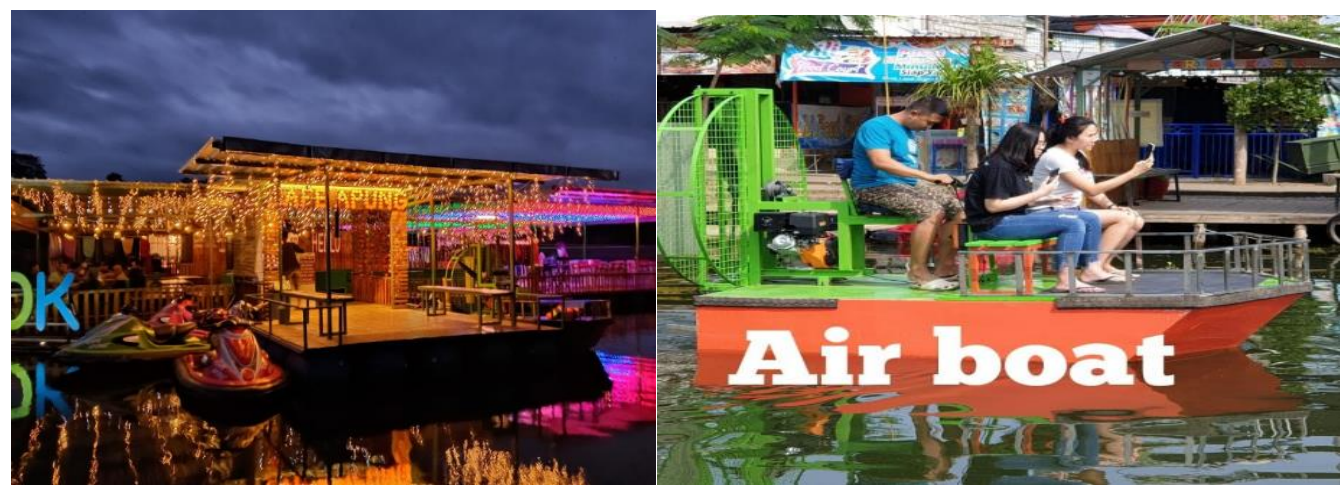

Gambar 3. Transformasi Café di Pedesaan

Sumber: https://cafeapungrowoklampok

Dari berbagai gambar diatas merupakan situasi dan transformasi yang sudah terjadi untuk memperbaiki café di wilayah pedesaan agar dapat menarik perhatian dan minat para pemuda dalam nangkring menikmati kopi sambil upload momen mereka bersama teman dan keluarga di media sosial yang mereka miliki.

Sedangkan transformasi café yang ada di perkotaan tidak begitu sulit seperti di wilayah pedesaan yang masih terhambat di akses jalan dan arsitektur. Jika, café diperkotaan ini lebih spesifik yang dulunya sebelum adanya perkembangan zaman café yang ada di kota malang masih belum ada alat-alat untuk membuat café dan belum mengenal istilah barista. Tidak seperti sekarang para pemuda mengalami perkembangan dimana mereka sekarang menikmati café dengan gaya arsitektur yang lebih bagus dan modern, kemudian banyak sekali spot-spot foto yang lebih instagramable dan menu makanan yang disajikan pun seperti layaknya café luar negeri atau café jas ibu kota. Pemuda di wilayah perkotaan lebih cenderung menikmati café-café yang terkenal mewah dan memiliki kualitas kopi yang baik, serta lokasi yang disajikan tersebut harus nyaman. Sebab, para pemuda di wilayah perkotaan lebih mementingka gaya hidup dan harga diri mereka. Kemudian menu makan yang disajikan pun juga bagus dan enak dilidah para pemuda millennial yang memandang status sosial mereka serta di pamerkan di media sosial yang mereka miliki juga.

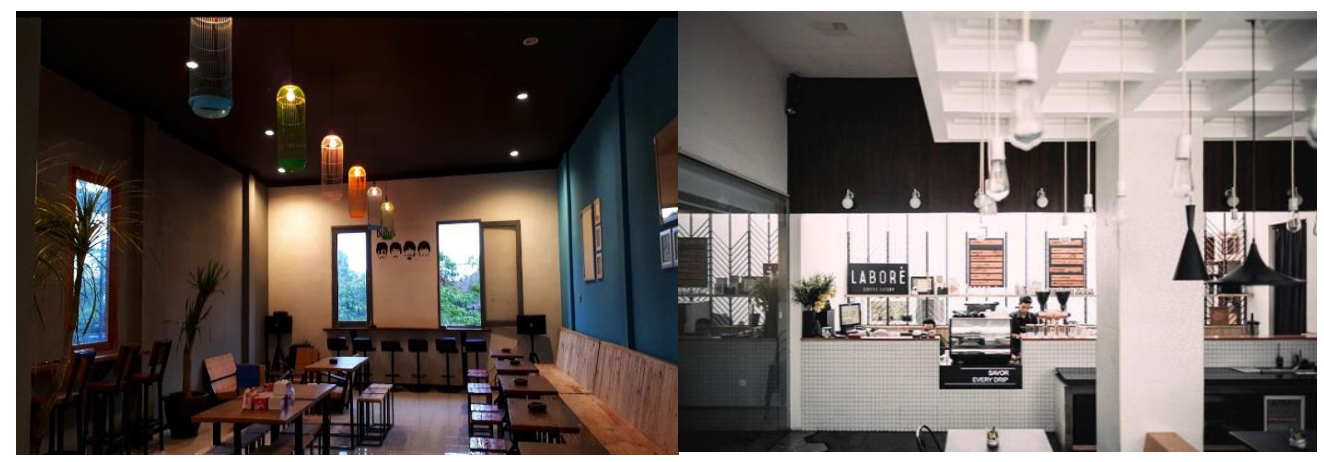

Gambar 4. Transformasi Café di Perkotaan 
Dari gambar diatas merupakan transformasi café yang ada di kota malang yang semakin memiliki keterbaruan dan berbagai inovasi untuk memperbaiki café mereka dalam bidang arsitektur maupun menu makanan lainnya untuk menarik perhatian para pemuda untuk nangkring di café tersebut menikmati waktu luang yang mereka miliki.

\section{Simpulan}

Dari penelitian ini dapat diketahui bahwa gaya hidup pemuda di wilayah pedesaan memiliki keterkaitan dengan budaya populer dan begitupun gaya hidup pemuda di perkotaan yang cukup mengenal baik budaya populer yang tengah berkembang dilingkungan mereka sebab budaya populer sangat mudah ditemukan melalui media internet. Dapat dikatakan bahwa para pemuda yang ada di wilayah pedesaan selalu mengikuti trend yang sedang berkembang di lingkungan masyarakat, tetapi mereka lebih menekankan kepada kepentingan yang mendesak dibandingkan harus memenuhi kebutuhan hanya sebatas untuk eksistensi dalam gaya hidup di pedesaan. Tetapi, pemuda perkotaan lebih suka melakukan berbagai cara dan tindakan untuk menyamakan gaya hidup yang trend di lingkungan masyarakat dengan mengorbankan uang yang cukup mahal.

Para pemuda desa juga mengenal media sosial seperti instagram dan whatsapp maupun facebook, oleh karena itu tidak asing jika pemuda desa mengikuti trend nangkring di café sembari menikmati waktu luang bersama keluarga dan minum kopi. Dengan hadirnya pembangunan café di wilayah pedesaan ini membuat perubahan gaya hidup pemuda desa, dimana dulu mereka nangkring di pinggir danau tetapi kini mereka nangkring di café apung layaknya di perkotaan saja dan ini disambut baik oleh para orang tua.

\section{Daftar Rujukan}

Bhara, M. (2009). Pengaruh pemberian kopi dosis bertingkat per oral 30 hari terhadap gambaran histologi hepar tikus wistar (Doctoral dissertation, Medical Faculty).

Fauzi, A., Punia, I. N., \& Kamajaya, G. (2017). Budaya nongkrong anak muda di Kafe (tinjauan gaya hidup anak muda di Kota Denpasar). Jurnal Ilmiah Sosiologi (SOROT), 1(1).

Herlyana, E. (2014). Fenomena coffee shop sebagai gejala gaya hidup baru kaum muda. THAQAFIYYAT: Jurnal Bahasa, Peradaban dan Informasi Islam, 13(1), 187-204.

Hidayatullah, N. A. (2017). Realitas kafe kekinian bagi kalangan mahasiswa pada Komunitas Instameet Surabaya (Doctoral dissertation, Universitas Airlangga).

Hull, G., Zacher, J., \& Hibbert, L. (2009). Youth, risk, and equity in a global world. Review of Research in Education, 33(1), 117-159.

Jaenudin, A. (2015). Gaya hidup nongkrong mahasiswa di kafe (Studi di Andromeda Cafe and Music, Jln. Jakarta No. 6, Malang, dan di Monopoli Garden House Cafe, Jln. Soekarno Hatta No. 28, Malang) (Doctoral dissertation, University of Muhammadiyah Malang).

Kaparang, O. M. (2013). Analisa gaya hidup remaja dalam mengimitasi budaya pop Korea melalui televisi. Acta Diurna Komunikasi, 2(2).

Khamdani, D. F. (2014). Tema sosial yang didialogkan oleh komunitas" Ngopi" di warung kopi Sarijan Malang (Doctoral dissertation, Universitas Negeri Malang).

Mannheim K. (t.t.). The Sociological Problem of Generation, Essays on the Sociologycal of Knowledge.

Mappiare. (1982). Psikologis Perkembangan Remaja. Usaha Nasional.

Pramita, D. A. (2016). Nongkrong di warung kopi sebagai gaya hidup mahasiswa di Mato Kopi Yogyakarta. ESocietas, 5(6).

Sears, Freedman, \& Peplau. (1985). Psikologi Sosial (5 ed.). Airlangga.

Storey, J. (2006). Cultural Theory and Popular Culture: AnIntroduction. NewYork: Pearson Prentice Hall. 
Jurnal Integrasi dan Harmoni Inovatif Ilmu-Ilmu Sosial, 1(4), 2021, 459-469

Sugiyono. (2015). Metode Penelitian Kombinasi (Mix Methods). Alfabeta.

Torkildsen, G. (2005). Leisure and recreation management. Psychology Press. 